\title{
NEW SPECIES OF SCHIZOSTACHYUM (POACEAE-BAMBUSOIDEAE) FROM THE ANDAMAN ISLANDS, INDIA
}

\author{
MUKTESH KUMAR \& M. REMESH \\ Botany Division, Kerala Forest Research Institute, Peechi 680-653, Trichur, Kerala, India
}

\section{SUMMARY}

Two new species of Schizostachyum Nees: S. andamanicum and S. kalpongianum, are described and illustrated.

Key words: Schizostachyum, Andaman Islands, India.

\section{INTRODUCTION}

During the revisionary studies on Indian bamboos the authors could undertake a survey in the Andaman Islands. Five species of bamboos, namely Bambusa atra, Dinochloa andamanica, Gigantochloa andamanica, Bambusa schizostachyoides, and Schizostachyum rogersii have so far been reported from the Andaman Islands (Munro, 1868; Gamble, 1896; Brandis, 1906; Parkinson, 1921). As a result of exploring different parts of the islands two interesting bamboos were collected. Critical examination revealed that they belonged to the genus Schizostachyum Nees and hitherto undescribed.

The genus Schizostachyum was described by Nees in 1829 based on Schizostachyum blumei. This genus is represented by about 45-50 species distributed in tropical and subtropical Asia from southern China throughout the Malaysian region, extending to the Pacific islands with the majority of species in Malaysia (Dransfield, 1983, 2000; Ohrnberger, 1999; Wong, 1995).

The genus is characterised by sympodial rhizomes; erect or straggling thin-walled culms; many branches of the same length arising from the node; indeterminate inflorescence; absence of glumes in the spikelets; presence of lodicules; slender ovary with long, glabrous stiff style which is hollow around a central strand of tissue; anthers usually with blunt apex. The bamboos collected from the Andaman Islands have straggling culms and are similar to Schizostachyum gracile (Munro) Holttum in certain characters but differ in several other characters. They belong to the species of Schizostachyum Nees which are here described as new.

1. Schizostachyum andamanicum M. Kumar \& Remesh, spec.nov. - Fig. 1

Schizostachyo gracili simile facie et culmi vaginae structura, ab eo in culmis effusissimis, internodiis brevibus (ad $20 \mathrm{~cm}$ longis), linea nodali conspicua ob annulam spongiosam, palea apice bifurcato, antheris brevibus apice obtuso pilorum tenuium fimbria, stigmatibus inaequalibus, caryopsidis rostro leniter curvato differt. - Typus: Remesh \& Viswakumar 20780 (holo KFRI; iso L, MH), India, Andaman Islands, Saddle Peak (North Andaman), $150-732 \mathrm{~m}, 25.05 .2000$. 


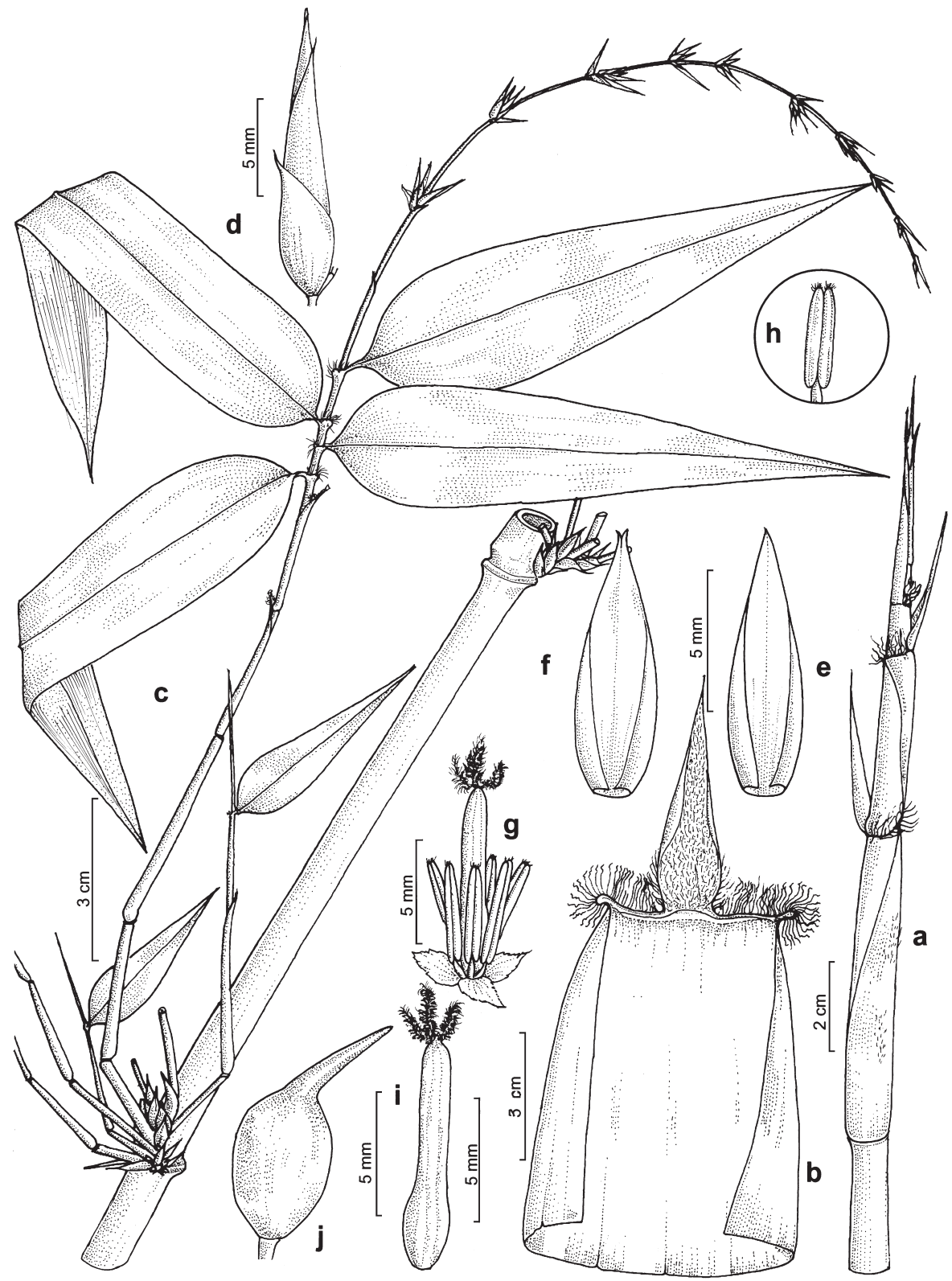

Fig. 1. Schizostachyum andamanicum M. Kumar \& Remesh. a. Young shoot; b. culm sheath; c. culm with flowering branch; d. spikelet; e. lemma; f. palea; g. floret with lodicule; h. stamen; i. ovary; j. fruit (all: Remesh \& Viswakumar 20780). 
A semiscandent sympodial bamboo with highly straggling culms arching over neighbouring plants and forming large bushes in hill slopes. Internode hollow, thin-walled, $18-22 \mathrm{~cm}$ long, 1.2-1.8 cm diam., pale green with purplish tinge when young, yellowish green to golden yellow when mature, clothed with minute silky hairs. Nodes somewhat swollen with a smooth spongy nodal ring. Branch complements typically a cluster of slender subequal branches. Young shoot greyish green with pale orange to purplish brown tinge. Culm sheath rigid, 13-16 cm long, at base 4-6 cm wide; at apex 4-5 $\mathrm{cm}$ wide, greyish green with purplish orange tinge, clothed by a few brown hairs. Auricle small elongated, dark brown up to $2 \mathrm{~mm}$ high with many long silky, white bristles coiled. Culm sheath blade linear lanceolate, 5-7 cm long, up to $0.8 \mathrm{~cm}$ wide, purplish brown bearing few bristles near the rounded basal part, inner surface sparsely hairy, hairs silky white, outer surface glabrous. Ligule up to $2 \mathrm{~mm}$ long. Leaf blade linear lanceolate, $8-32$ by $2.6-4.8 \mathrm{~cm}$, base broadly attenuate, glabrous. Leaf sheath glabrous, margin serrulate, auricle small, $1 \mathrm{~mm}$ high with few bristles. Inflorescence indeterminate, terminating leafy branches. Spikelets arranged in a group of semiverticillate clusters at each node, thin, up to $1.2 \mathrm{~cm}$ long, 1-flowered. Lemma membranous, up to 9 by $4 \mathrm{~mm}$, bearing a rachilla extension at the base. Palea membranous, up to 7 by $5 \mathrm{~mm}$, apex bifurcated. Lodicules 3, unequal, 2 large ( 3 by $2 \mathrm{~mm}, 3$ by $3 \mathrm{~mm}$ ) and one small ( 2 by $1 \mathrm{~mm})$, margins and apices toothed. Stamens 6 . Filaments free. Anthers 2.5-3 mm long, apex obtuse, unequal, with fine hairs. Ovary slender, glabrous. Style flattened up to $1 \mathrm{~cm}$ long. Stigma 3, unequal, plumose, tufted. Caryopsis up to 15 by $4 \mathrm{~mm}$ with a globular basal part and a slightly bent beak.

Distribution - India, Andaman Islands, North Andaman, Saddle Peak.

Ecology - Occurring in hilltop stunted evergreen forests, altitude 350-732 m.

Flowering \& fruiting - Flowering occurs irregularly throughout the year.

Etymology - This species is named after the collection locality, Andaman Islands, which is a treasure house of rare and endemic plant species.

Note - Schizostachyum andamanicum is similar to S. gracile (Munro) Holttum in general appearance and culm sheath structure, but it differs from the latter in having a highly straggling culm, short internodes (up to $20 \mathrm{~cm}$ ), a well-marked nodal line with a spongy ring, short anthers with obtuse apex and a fringe of fine hairs, unequal stigma and caryopsis with a slightly bent beak (Table 1).

2. Schizostachyum kalpongianum M. Kumar \& Remesh, spec.nov. - Fig. 2

Schizostachyo gracili simile facie et culmi vaginae natura, etc., culmo effuso, internodiis longis (ad $45 \mathrm{~cm})$, culmi vaginae ligula marginibus undulatis, spiculis bifloris, caryopsidis pagina projecturis proprie angulosis distinctum. - Typus: M. Kumar \& Remesh 20778 (holo KFRI; iso L, MH), India, Andaman Islands, North Andaman, Kalpong Damsite, $\pm 200 \mathrm{~m}, 22.05 .2000$.

Straggling sympodial bamboo, culms up to $5 \mathrm{~m}$ tall, sometimes arching over neighbouring trees. Internodes up to $40-45 \mathrm{~cm}$ long, hollow, thin-walled, $2-2.5 \mathrm{~cm}$ diam., pale green with brownish hairs when young, becoming dull green and glabrous with white powdery below the nodes. Branch complements typically a cluster of slender subequal branches. Young shoots pale orange red. Culm sheaths $15-20 \mathrm{~cm}$ long, 9-14 $\mathrm{cm}$ wide at the base, rigid, orange red with golden brown to dark brown hairs. Auricle 


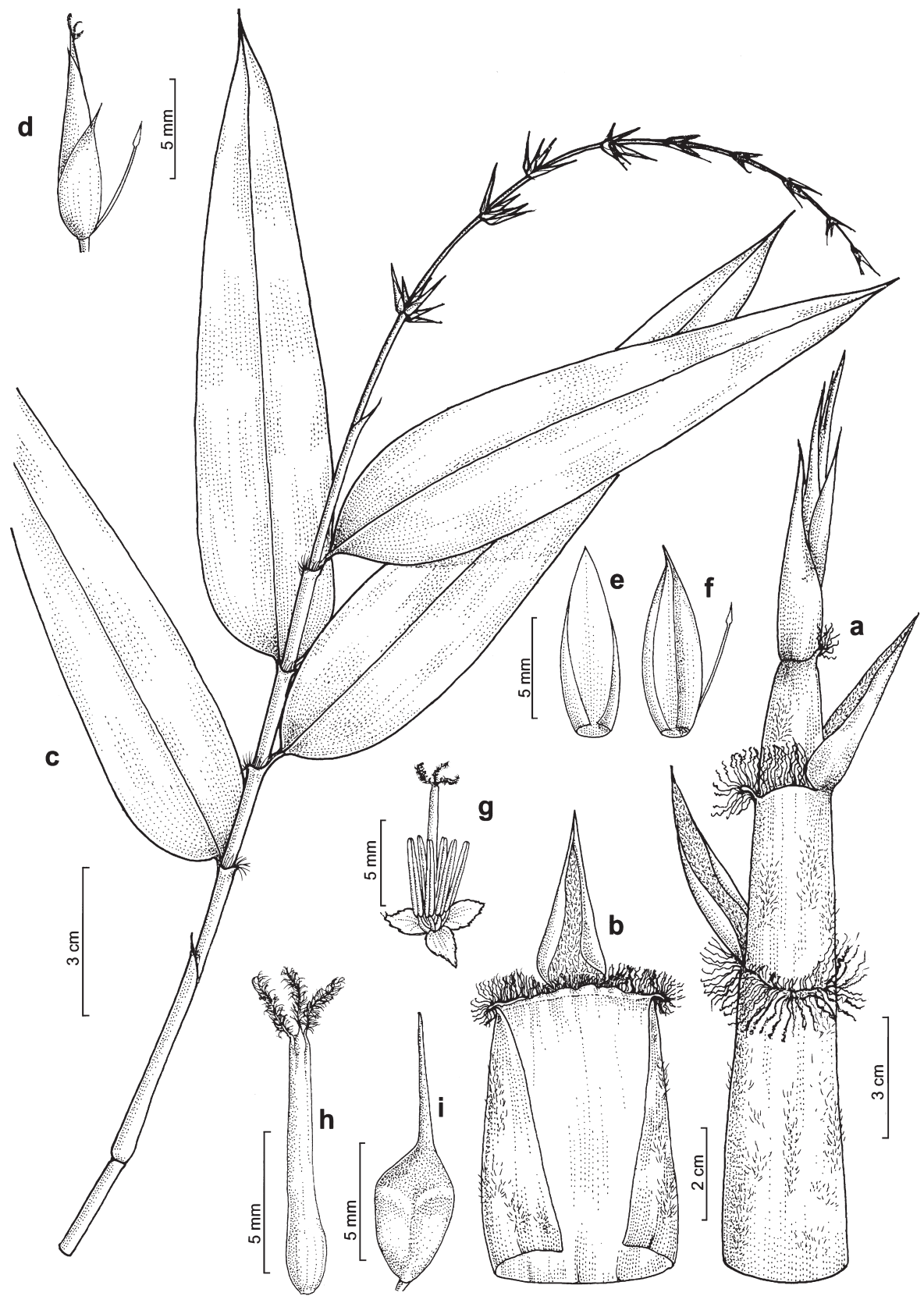

Fig. 2. Schizostachyum kalpongianum M. Kumar \& Remesh. a. Young shoot; b. culm sheath; c. flowering twig; d. spikelet; e. lemma; f. palea with rachilla extension; g. floret with lodicule; h. ovary; i. fruit (all: Kumar \& Remesh 20778). 
conspicuous up to $4 \mathrm{~mm}$ high with long bristles, tip coiled up to $2.5-3 \mathrm{~cm}$. Blade $8-12$ $\mathrm{cm}$ long, $2.5 \mathrm{~cm}$ wide near the base, brownish orange, rigid, conical, outer surface glabrous, inner surface with silky white hairs (up to $9 \mathrm{~mm}$ ), base slightly rounded, $1.6-1.8 \mathrm{~cm}$ wide at junction with the sheath, apex acuminate, from the inner side of the blade numerous silky white hairs originated behind the ligule. Ligule short, up to $4 \mathrm{~mm}$ long, margin wavy. Leaves linear lanceolate, base broadly attenuate, glabrous on both surfaces. Leaf blade $22-34$ by $3.5-5 \mathrm{~cm}$. Leaf sheath with appressed white hairs, hairs caducous. Auricle up to $2 \mathrm{~mm}$ long, bearing white bristles. Inflorescence indeterminate, terminating leafy branches. Spikelets arranged in a group of semiverticillate clusters at each node, thin, 1.2-1.3 cm long, 2-flowered, consisting of a sterile and fertile floret and a rachilla extension of 7-8 $\mathrm{mm}$ long, bearing a rudimentary floret (up to $2 \mathrm{~mm}$ long). Lemma 7 by $4 \mathrm{~mm}$. Palea $8-9$ by $5-6 \mathrm{~mm}$, glabrous, apex fringed with fine hairs. Lodicules 3, equal up to 3 by $2 \mathrm{~mm}$, ovate, apex acuminate, margin serrate. Stamens 6 . Anthers up to $5 \mathrm{~mm}$ long, apex rounded. Filaments free. Ovary tubular, glabrous, $9 \mathrm{~mm}$ long. Style glabrous with well-marked stigmatic base, bearing 3 short stigmas at apex. Stigma equal, pinkish and highly plumose. Caryopsis $15-18$ by $2-6 \mathrm{~mm}$, ovoid, rounded basal part an acute tip with a long beak, surface with angular projections, glabrous.

Table 1. Distinctions between Schizostachyum gracile, S. andamanicum and S. kalpongianum.

\begin{tabular}{|c|c|c|c|}
\hline characters & S. gracile & S. andamanicum & S. kalpongianum \\
\hline culm & $\begin{array}{l}\text { erect, } 1.5-2 \mathrm{~cm} \text { diam. } \\
\text { with drooping tips }\end{array}$ & $\begin{array}{l}\text { highly straggling, } \\
1.2-1.8 \mathrm{~cm} \text { diam. }\end{array}$ & $\begin{array}{l}\text { straggling, } 2-2.5 \mathrm{~cm} \\
\text { diam. }\end{array}$ \\
\hline internode & $\begin{array}{l}25-35 \mathrm{~cm} \text { long, node } \\
\text { smooth }\end{array}$ & $\begin{array}{l}18-20 \mathrm{~cm} \text {, nodal line with } \\
\text { a ring of spongy tissue }\end{array}$ & $40-45 \mathrm{~cm}$, node smooth \\
\hline culm-sheath & $\begin{array}{l}\text { blade broadly triangular, } \\
\text { inner surface glabrous }\end{array}$ & $\begin{array}{l}\text { blade linear lanceolate, } \\
\text { inner surface of the blade } \\
\text { sparsely hairy, hair silky } \\
\text { white }\end{array}$ & $\begin{array}{l}\text { blade broadly triangular, in } \\
\text { between the juncture of } \\
\text { ligule and blade a row of } \\
\text { silky white hairs, hairs } \\
\text { up to } 9 \text { mm long, inner } \\
\text { surface of the blade } \\
\text { densely clothed with } \\
\text { long silky white hairs }\end{array}$ \\
\hline auricle & $\begin{array}{l}\text { lobes up to } 5 \mathrm{~mm} \text { high, } \\
\text { bristles up to } 8 \mathrm{~mm} \text { long }\end{array}$ & $\begin{array}{l}\text { lobes up to } 2 \mathrm{~mm} \text { high, } \\
\text { bristles up to } 1.5 \mathrm{~cm} \text { long }\end{array}$ & $\begin{array}{l}\text { lobes } 4 \mathrm{~mm} \text {, bristles up to } \\
3 \mathrm{~cm} \text { long }\end{array}$ \\
\hline ligule & $\begin{array}{l}5 \mathrm{~mm} \text { high with a fringe } \\
\text { of fine hairs }\end{array}$ & up to $2 \mathrm{~mm}$ high, glabrous & $\begin{array}{l}\text { up to } 4 \mathrm{~mm} \text { high, margin } \\
\text { wavy, glabrous }\end{array}$ \\
\hline spikelet & 1-flowered & 1-flowered & 2-flowered \\
\hline palea & $\begin{array}{l}12 \text { mm long, apex acute, } \\
\text { sparsely hairy }\end{array}$ & $\begin{array}{l}7 \text { mm long, apex } \\
\text { bifurcated, glabrous }\end{array}$ & $\begin{array}{l}9 \mathrm{~mm} \text { long, apex acute, } \\
\text { fringed with fine hairs }\end{array}$ \\
\hline anthers & acute at apex, $4 \mathrm{~mm}$ long & $\begin{array}{l}\text { obtuse at apex, up to } \\
3 \mathrm{~mm} \text { long, fringed with } \\
\text { fine hairs }\end{array}$ & $\begin{array}{l}\text { obtuse at apex, up to } \\
5 \mathrm{~mm} \text { long, glabrous }\end{array}$ \\
\hline stigma & equal & unequal & equal \\
\hline caryopsis & $\begin{array}{l}\text { surface smooth, beak } \\
\text { straight }\end{array}$ & $\begin{array}{l}\text { surface smooth, beak } \\
\text { slightly bent }\end{array}$ & $\begin{array}{l}\text { surface with angular } \\
\text { projections, beak straight }\end{array}$ \\
\hline lodicules & equal & unequal & nearly equal \\
\hline
\end{tabular}


Distribution - India, Andaman Islands, North Andaman, Kalpong Damsite, Panighat, Bikentikri, Aerial Bay and Kalighat.

Ecology - Growing near the ecotone of moist deciduous forest at an altitude of $50-250 \mathrm{~m}$.

Flowering \& fruiting - Flowering occurs irregularly throughout the year.

Etymology - This species is named after the type locality, Kalpong.

Notes - 1. Schizostachyum kalpongianum is similar to S. gracile (Munro) Holttum in appearance and nature of culm sheath etc. but it is distinct from the latter in having a straggling culm and long internodes (up to $45 \mathrm{~cm}$ ), characteristic features of culm sheath such as ligule, blade and caryopsis oblong with angular projections (Table 1).

2. Schizostachyum kalpongianum is also closely related to $S$. andamanicum in appearance but differs in having a less straggling culm habit, large culms with long internodes (up to $45 \mathrm{~cm}$ ), conical blade with silky white to golden brown hairs on the inner surface, a fringe of silky white hairs in between the blade juncture and ligule, equal sized stigma and lodicule, caryopsis with angular projections and a straight beak.

\section{ACKNOWLEDGEMENTS}

The authors wish to acknowledge Dr. J.K. Sharma, Director, Kerala Forest Research Institute, Peechi for his keen interest and encouragement and for the facilities. We express our sincere thanks and gratitude to Mr. K. Sasidharan Nair, IFS, PCCF, Kerala; Mr. G.P. Shukla, IFS, PCCF, Andaman \& Nicobar Circle; Mr. C. Ramhaluna Laha, IFS, CF, Andaman \& Nicobar, Mr. R.S.C. Jayaraj, DCF, Silviculture Division, Andaman \& Nicobar Circle, for all the help rendered and for the permission and organization of our field trip during the stay at the Andamans. Thanks are also due to Mr. Dileep D'souza and Mr. Ajaykumar, Range Officers, who had taken lot of pains for accompanying us during the field trips and for their help in the field. Sincere thanks are due to Dr. J.F. Veldkamp, Nationaal Herbarium Nederland, Universiteit Leiden branch, for providing the Latin diagnoses. The authors are thankful to the Department of Science \& Technology, Govt. of India, New Delhi, for the financial support to conduct this study. The help rendered by Mr. T.R. Viswakumar, during the field trip at the Andamans and for helping in various ways during the preparation of this manuscript is gratefully acknowledged. The authors also wish to express their thanks for the critical comments of the unknown referees for the improvement of the manuscript.

\section{REFERENCES}

Brandis, D. 1906. Indian Trees. London.

Dransfield, S. 1983. Notes on Schizostachyum (Gramineae-Bambusoideae) from Borneo and Sumatra. Kew Bull. 38: 321-332.

Dransfield, S. 2000. Schizostachyum khoonmengii, a new species of bamboo (Poaceae-Bambusoideae) from Brunei Darussalam. Kew Bull. 55: 491-494.

Gamble, J.S. 1896. The Bambuseae of British India. Ann. Roy. Bot. Gard. Calcutta 7.

Munro, W. 1868. A monograph of the Bambusaceae. Trans. Linn. Soc. London 26: 1-157.

Nees von Esenbeck, C.G.D. 1829. Agrostologia Brasiliensis seu descriptio graminum in imperio brasiliensis huc usque dectectorum. Stuttgart \& Tübingen.

Ohrnberger, D. 1999. The bamboos of the world: 330-336. Elsevier, Amsterdam, The Netherlands.

Parkinson, C.E. 1921. A forest flora of the Andaman Islands: 271-272. Dehra Dun.

Wong, K.M. 1995. The bamboos of Peninsular Malaysia: 163-181. FRIM, Kepong, Kuala Lumpur. 